\title{
Assessment of Penicillium bilaii inoculation in wheat (Triticum aestivum L.) for improving growth, yield and phosphorus availability in Mollisols of India
}

\author{
Santosh Chandra Bhatt ${ }^{1^{*}}$, Sovan Debnath ${ }^{2}$, Navneet Pareek ${ }^{1}$ \\ ${ }^{1}$ Department of Soil Science, G.B. Pant University of Agriculture and Technology, Pantnagar - 263145 \\ (Uttarakhand), INDIA \\ ${ }^{2}$ ICAR-Central Institute of Temperate Horticulture, Regional Station, Mukteshwar, Nainital - 263138 \\ (Uttarakhand), INDIA \\ *Corresponding author. Email: sbhatt3713@gmail.com
}

Received: July 8, 2015; Revised received: December 8, 2015; Accepted: March 7, 2016

\begin{abstract}
A field experiment was carried out with an aim to study the influence of two strains of Penicillium bilaii (PB -201 and PB-208) inoculation along with superphosphate application on growth, yield and P uptake of wheat (cv. PBW-343) and, also to examine the inoculation effect on $P$ availability, forms of $P$ and soil properties in Mollisols of Uttarakhand, India. The results showed that both strains of $P$. bilaii effectively solubilized tri-calcium phosphate in Pikovskaya agar medium, which was much higher over native fungal isolates. Wheat seed inoculation with $P$. bilaii strains along with superphosphate levels significantly influenced shoot height, shoot dry weight, number of total and effective tillers, yield attributes, yield components, tissue content and uptake of $\mathrm{P}$. The treatment $\mathrm{T}_{7}(P$. bilaii, strain PB-208 $+50 \%$ P) has resulted into the highest amount of shoot height $(87.9 \mathrm{~cm}$ at $90 \mathrm{DAS})$, shoot dry weight $(1.5$ and $3.8 \mathrm{~g}$ at 60 and 90 DAS, respectively), grain $\left(66.8 \mathrm{q} \mathrm{ha}^{-1}\right)$ and straw yield $\left(42.7 \mathrm{q} \mathrm{ha}^{-1}\right)$ and $P$ uptake $(26.5 \mathrm{~kg}$ ha $\left.{ }^{1}\right)$. The Olsen- $P$, organic carbon, dehydrogenase activity and fungal populations also increased in soil inoculated with $P$. bilaii strains combined with superphosphate application compared to the control soil. The conjoint use of the fungal strains with or, without $P$ fertilization has developed an antagonistic interaction that has caused decline in yield, tissue content and uptake of $\mathrm{P}$ and its availability in soil. In conclusion, it is possible to reduce the rate of soluble $\mathrm{P}$-fertilizer added by $50 \%$ without reducing yield, if wheat is inoculated with $\mathrm{P}$-solubilizing fungi like $P$. bilaii.
\end{abstract}

Keywords: Mollisols, Penicillium bilaii, Phosphorus, P-solubilizing fungi, Wheat

\section{INTRODUCTION}

Phosphorus (P) deficiency is a constraint to plant growth worldwide (Khan and Joergensen, 2009). Deficiency of $\mathrm{P}$ leads to severe growth retardation, reduced tillering in cereal, poor quality and low yields (Havlin et al., 2009). To increase agricultural production, large amounts of $\mathrm{P}$ fertilizers are widely applied. Unfortunately, about $85-90 \%$ of the added $\mathrm{P}$ as chemical fertilizer becomes unavailable to plants in the year of application due to adsorption and precipitation with $\mathrm{Fe}, \mathrm{Al}$ and $\mathrm{Ca}$ in the soil (Brady and Weil, 2008; Khan and Joergensen, 2009). Additionally, the conventional methods of $P$ fertilization cause unsatisfactory and unsustainable environmental and economic problems and, lead to an overall reduction in soil fertility (Xiao et al., 2008). Hence, researchers are desperate to find alternate strategies that can ensure sustainable crop productions while protecting the soil health and environment. In this context, use of microbial inoculants capable of phosphate solubilization in agriculture represent an environmentally-friendly and economically sound alternative to the more expensive superphosphates and possess a greater agronomic utility (Khan et al., 2007).
Several soil microorganisms have the ability to solubilize insoluble mineral and organic phosphates, converting them into soluble forms that are available to plants through different mechanisms, such as acidification, chelation, exchange reactions and production of organic acids (Rodriguez et al., 2004; Relwani et al., 2008). Penicillium bilaii (PB), a rhizospheric filamentous fungus, is considered to be a key group of soil microflora involved in $\mathrm{P}$ cycling. The fungus is reported to increase dry matter production, growth rate, yield, and $\mathrm{P}$ uptake in many field grown crops in growth chamber and field experiments (Kucey et al., 1989, Saber et al., 2009). PB inoculation increased the $\mathrm{NaHCO}_{3}$-extractable $\mathrm{P}$ and the incidence of $\mathrm{P}$ solubilizing fungi in the rhizosphere (Kucey, 1988). The major low molecular weight organic acids produced by PB are oxalic and citric acid (Cunningham and Kuiack, 1992). This indirect evidence suggests that PB may increase the availability of $\mathrm{P}$ to the plant by releasing organic acids, which may act to acidify localized areas of the rhizosphere, or act as a chelator of cationic partners of the phosphate anion (Kucey, 1988). Most inoculants based studies have focused on the ability of specific fungi or bacteria to directly solu- 
bilize $\mathrm{P}$ from inorganic pools in the soil leading to increased soluble $\mathrm{P}$ available for plant uptake (Whitelaw, 2000). Inoculants may however, potentially increase soil soluble $\mathrm{P}$ by other mechanisms such as releasing $\mathrm{P}$ from organic pools.

Interaction between $P$. bilaii and wheat (Triticum aestivum L.) as a host plant is of great significance because, solubilization of insoluble phosphates and its subsequent availability can increase growth and grain yield production in wheat. Despite much of the work has gone into the study on $\mathrm{P}$ solubilization through inoculation of $\mathrm{P}$ solubilizing microorganisms with phosphate-rock (RP), tri-calcium phosphate (TCP) or, even without phosphate fertilization (Tarafdar and Rao, 1996; Wahid and Mehana, 2000; Singh and Reddy, 2011), there have been very few developments that have led to commercially available $\mathrm{P}$ solubilizing inoculants in combination with superphosphate that have a consistent plant growth response in soils. The main objective of our study was to investigate the effect of $P$. bilaii inoculation on growth, yield, yield attributing parameters and uptake of phosphorus in wheat. We also intended to measure the influence of $P$. bilaii inoculation on various forms of phosphorus and its availability and some selected soil properties.

\section{MATERIALS AND METHODS}

Fungal strains and media: Two effective strains of $P$. bilaii viz. PB-201 and PB-208 were procured from M/ s. Novozymes Pvt. Ltd. Bengaluru, India for conducting the experiment. The procured Penicillium strains were maintained as slant culture on Pikovaskaya (PKV) agar medium modified by Sundara Rao and Sinha (1963). Morphologically all the colonies formed on PKV agar medium were uniform without any contaminants.

P solubilization: Qualitative estimation of phosphate solubilization efficiency of the fungi was carried out by performing the experiment of halo zone formation around the fungal growth after inoculation on PKV agar medium, amended with tri-calcium phosphate (TCP) and, incubated for 3 and 7 days at $28 \pm 2{ }^{\circ} \mathrm{C}$. In addition, appropriate serial dilutions of soil were also made and dilutions were plated on PKV media to isolate soil fungi present in the study site capable of dissolving phosphates. The fungal isolate from soil and procured $P$. bilaii strains were incubated and observed for development of clear halo zone around the colonies. Transparent zone of clearing around microbial colonies indicate the extent of phosphate solubilization (Sundara Rao and Sinha, 1963). The basic objective of this experiment was to observe the phosphate solubilization efficiency of the procured $P$. bilaii strains compared to soil fungal isolates. The decoding of isolates isolated from soil and procured culture of $P$. bilaii strains are given below:

Here, $F_{1} W_{1}, F_{2} W_{3}$ and $F_{3} B_{1}$ were the unidentified phos-

$\begin{array}{ll}\text { Code } & \text { Detail } \\ \mathrm{Pb}_{1} & \text { P. bilaii } \mathrm{PB}-201 \\ \mathrm{~Pb}_{2} & \text { P. bilaii } \mathrm{PB}-208 \\ \mathrm{~Pb}_{1}+\mathrm{Pb}_{2} & \text { P. bilaii } \mathrm{PB}-201 \text { and } \mathrm{PB}-208 \\ \mathrm{~F}_{1} \mathrm{~W}_{1} & \text { Fungi } 1 \text { white } 1 \\ \mathrm{~F}_{2} \mathrm{~W}_{3} & \text { Fungi } 2 \text { white } 3 \\ \mathrm{~F}_{3} \mathrm{~B}_{1} & \text { Fungi } 3 \text { black } 1\end{array}$

phate solubilizing fungi isolated from soil. The terms like 'white' and 'black' referred to here, was designated on the basis of colour of the fungal spores.

Study site and soil: The study was carried out in the rabi season (cooler winter-spring period, December 2009 to April 2010) at GBPUA\&T, Pantnagar, Uttarakhand, India $\left(29^{\circ} \mathrm{N}, 79^{\circ} 3^{\prime} \mathrm{E} ; 244 \mathrm{~m} \mathrm{msl}\right)$. The site is characterized as humid sub-tropical having hot dry summers and cold winters with annual maximum and minimum air temperature usually ranges between 40 to $3{ }^{\circ} \mathrm{C}$, respectively. The mean annual rainfall ranges from 1300 to $1500 \mathrm{~mm}$, mostly confined from June to September. The total precipitation during the course of this study was $35.6 \mathrm{~mm}$ and average temperature ranged from 11.7 to $28.9{ }^{\circ} \mathrm{C}$. The soil of study area is derived from calcareous alluvium and, has been classified as Mollisol (Typic Hapludolls, USDA Classification). Table 1 shows initial properties of the soil (0-15 $\mathrm{cm})$.

Experimental design and treatments: Seeding of wheat ( $c v$. PBW-343) was done in December, 2009. Prior to seeding, seeds were treated with the respective $P$. bilaii strains by using $6 \mathrm{ml}$ of fungi inoculum $\mathrm{kg}^{-1}$ wheat seed. The treated seeds were dried for half an hour under shed and, then sown in individual plots $(2.4$ $\times 3.0 \mathrm{~m})$ at $5 \mathrm{~cm}$ soil depth. Soil was irrigated once before sowing to ensure adequate soil water for seedling establishment and, then regularly during crop growth to maintain sufficient soil moisture. A uniform dose of $120 \mathrm{~kg} \mathrm{~N} \mathrm{ha}^{-1}$ in three equal splits (pre-sowing, 45 and 70 days after sowing) and $40 \mathrm{~kg} \mathrm{~K}_{2} \mathrm{O} \mathrm{ha}^{-1}$ as basal was applied through urea and muriate of potash, respectively. Other recommended agronomic practices were also followed throughout the experiment for raising the crop. Phosphorus, through superphosphate $\left(16 \% \mathrm{P}_{2} \mathrm{O}_{5}\right.$ approx.), was applied in accordance to the treatments and, a recommended dose of $65 \mathrm{~kg} \mathrm{P}_{2} \mathrm{O}_{5} \mathrm{ha}^{-1}$ was considered as $100 \% \mathrm{P}$. The following treatments consisting combinations of different levels of superphosphate with

$\begin{array}{ll}\text { Treatments } & \\ \text { Uninoculated + 0\% P } & \mathrm{T}_{1} \text { (Control) } \\ \mathrm{Pb}_{1}+0 \% \mathrm{P} & \mathrm{T}_{2} \\ \mathrm{~Pb}_{2}+0 \% \mathrm{P} & \mathrm{T}_{3} \\ \mathrm{~Pb}_{1}+\mathrm{Pb}_{2}+0 \% \mathrm{P} & \mathrm{T}_{4} \\ \mathrm{Uninoculated}+50 \% \mathrm{P} & \mathrm{T}_{5} \text { (Control) } \\ \mathrm{Pb}_{1}+50 \% \mathrm{P} & \mathrm{T}_{6} \\ \mathrm{~Pb}_{2}+50 \% \mathrm{P} & \mathrm{T}_{7} \\ \mathrm{~Pb}_{1}+\mathrm{Pb}+50 \% \mathrm{P} & \mathrm{T}_{8} \\ \mathrm{Uninoculated}+100 \% \mathrm{P} & \mathrm{T}_{9} \text { (Control) } \\ \mathrm{Pb}_{1}+100 \% \mathrm{P} & \mathrm{T}_{10} \\ \mathrm{~Pb}_{2}+100 \% \mathrm{P} & \mathrm{T}_{11} \\ \mathrm{~Pb}_{1}+\mathrm{Pb}_{2}+100 \% \mathrm{P} & \mathrm{T}_{12} \\ & \end{array}$


and without $P$. bilaii strains were laid out in randomized block design in four replications:

The crop was harvested at 131 days after sowing (DAS), dried in shed and the grains were separated and, yield was recorded plot wise for grain and straw.

Growth and yield attributes: Four growth parameters viz. shoot height, shoot dry weight and number of total and effective tillers, were selected for the study of growth in wheat. Five plants from each plot were selected randomly and, shoot height was measured at 60 and 90 DAS and averaged. For dry weight, three plants were uprooted from each plot at 60 and 90 DAS, washed and then dried at $70^{\circ} \mathrm{C}$ to constant weight, and their dry weights were averaged. The number of total and effective tillers was measured at harvesting from a square meter area of net plot area. Yield attributes were estimated in terms of number of spikelets per ear, number of grains per ear and weigh of 1000 grains (test weight). Ten ears were collected randomly from each plot at harvesting and, number of spikelets and grains were counted and averaged.

P uptake: The harvested samples were analyzed for $\mathrm{P}$ contents in grain and straw by digestion with $\mathrm{HNO}_{3}: \mathrm{HClO}_{4}$ (4:1) mixture and, subsequent determination by vanadophosphomolybdic acid (Jackson, 1973). Dry matter yield and nutrient content of grain and straw were used to determine uptake of $\mathrm{P}$.

Soil analysis: Composite soil samples of $0-15 \mathrm{~cm}$ depth were collected after harvesting. Soil samples were air dried, processed and sieved through $2 \mathrm{~mm}$ sieve and stored for further analytical purpose. A portion of soil sample was separated prior to air drying and stored at $4^{\circ} \mathrm{C}$ for determination of dehydrogenase activity (DHA) and fungal population. Available $\mathrm{P}$ in soil was determined following Olsen method (Olsen et al., 1954). Inorganic $\mathrm{P}\left(\mathrm{P}_{\mathrm{i}}\right)$ was measured by nonignition and, organic $\mathrm{P}\left(\mathrm{P}_{\mathrm{o}}\right)$ was determined following by ignition method (Walker and Adams, 1958). Total $\mathrm{P}$ $\left(\mathrm{P}_{\mathrm{t}}\right)$ was estimated by digestion with $\mathrm{HClO}_{4}$ and, the digested residue was further fused with $\mathrm{Na}_{2} \mathrm{CO}_{3}$ to extract all remaining $\mathrm{P}$ from each sample (Jackson, 1973). The soil was also analyzed for $\mathrm{pH}$, organic $\mathrm{C}$ (Walkley and Black, 1934), mineralizable-N (Subbiah and Asija, 1956) and acetate-extractable K (Jackson, 1973). DHA in samples was measured by reduction of triphenyl tetrazolium chloride (TTC) to triphenyl formazan (TPF) using colorimetric procedure of Tabatabai (1982). Population of fungi was determined by plate count method using Martin's Rose Bengal streptomycin agar medium (Subba Rao, 1986). Colonies were counted in replicates of $10^{-3}, 10^{-4}$ and $10^{-5}$ dilutions and their averages were multiplied with dilution factor to obtain the fungal population (colony forming unit, CFU). The laboratory and field data were analyzed statistically for analysis of variance (ANOVA) by procedure outlined by Gomez and Gomez (1984). The level of significance was tested at $p \leq 0.05$.

\section{RESULTS}

In vitro phosphate solubilization efficiency of Penicillium strains and soil isolates: The tested fungi showed different abilities to dissolve tri-calcium phosphate in PKV agar medium. Phosphate solubilizing efficiency of soil isolates and $P$. bilaii strains was graded based on diameter of halo zones by assigning the positive (+) marks and given in Table 2 and Fig. 1 . Higher number of (+) marks indicates better solubilization efficiency. It is clearly seen from the table that phosphate solubilization efficiency of the procured $P$. bilaii strains was much higher over the fungal isolates from soil. It is also evident that phosphate solubilization by the combined inoculation of $P$. bilaii strains $\left(\mathrm{Pb}_{1}+\mathrm{Pb}_{2}\right)$ was less, as compared to the strains individually. They can be arranged in a decreasing order, according to their efficiency, as follows: $\mathrm{Pb}_{2}>\mathrm{Pb}_{1}>\mathrm{Pb}_{1}+\mathrm{Pb}_{2}>\mathrm{F}_{2} \mathrm{~W}_{3}>\mathrm{F}_{1} \mathrm{~W}_{1}>\mathrm{F}_{3} \mathrm{~B}_{1}$.

Growth and yield attributes: The shoot height ranged from 41.4 to 53.9 and 76.3 to $87.9 \mathrm{~cm}$ among different treatments at 60 and 90 DAS, respectively (Fig. 2a). It can be seen from the figure that highest shoot height was recorded in $\mathrm{T}_{10}$ and $\mathrm{T}_{7}$ at 60 and 90 DAS, respectively. And, the lowest was recorded in $\mathrm{T}_{1}$ at 60 and 90 days after sowing. However, inoculation effect of both the strains of PB along with phosphate fertilization on shoot height was statistically nonsignificant. The treatments significantly increased shoot dry weight at 60 DAS to their corresponding control while, they failed to influence the same at 90 DAS. Like shoot height, $\mathrm{T}_{7}$ also registered the maximum shoot dry weight at both 60 and 90 DAS (Fig. 2b). The total and effective tillers $\mathrm{m}^{-2}$ ranged from 219.0 to 257.3 and 205.0 to 249.0 in $\mathrm{T}_{1}$ and $\mathrm{T}_{7}$, respectively (Fig. 3a). They were also statistically significant compared to their respective control. It was interesting to observe that individual effect of the fungal strains was more than their conjoint use, without $\mathrm{P}$ fertilization, in all of the growth parameters. Even, the effect of conjoint use of the fungal strains with $\mathrm{P}$ fertilization on plant growth was at par, with their lone use combined with $\mathrm{P}$ fertilization. Number of spikelets and grains ear ${ }^{-1}$ were also affected significantly by the treatments. Highest increase in numbers was observed in $\mathrm{T}_{7}$ while, the lowest was recorded in $\mathrm{T}_{1}$ (Fig. 3b). Like other yield attributes, maximum test weight was also recorded in $\mathrm{T}_{7}(44.3 \mathrm{~g})$.

Yield components and $P$ uptake: Table 3 indicates that the yield components of the tested crop significantly increased as a result of soil inoculation with $P$. bilaii strains. However, this effect was not same for both the inoculants. Moreover, the influence of $P$. bilaii (strain PB-208) on grain and straw yield was higher over the combined inoculation of the strains, with $\mathrm{P}$ fertilization. The influence of the treatments $\mathrm{T}_{2}$, $\mathrm{T}_{3}$ and $\mathrm{T}_{4}$ on grain yield was at par as compared to their respective control $\left(\mathrm{T}_{1}\right)$. Inoculation of $\mathrm{Pb}_{2}$ with $50 \% \mathrm{P}\left(\mathrm{T}_{7}\right)$ increased the highest grain and straw yield 
Table 1. Initial soil and microbial properties of the experimental site.

\begin{tabular}{|c|c|c|c|c|}
\hline S.N. & Soil property & Values & Method employed & Reference \\
\hline \multirow[t]{5}{*}{1.} & Mechanical-analysis & & Hydrometer & Piper (1967) \\
\hline & Sand $(\%)$ & 50 & & \\
\hline & Silt $(\%)$ & 30 & & \\
\hline & Clay $(\%)$ & 20 & & \\
\hline & Textural class & Sandy loam & & \\
\hline 2. & $\mathrm{pH}$ & 7.47 & $1: 2(\mathrm{w} / \mathrm{v})$ soil to water suspension & Jackson (1973) \\
\hline 3. & Electrical conductivity $\left(\mathrm{dS} \mathrm{m}{ }^{-1}\right)$ & 0.42 & Conductivity bridge & Jackson (1973) \\
\hline 4. & Organic $\mathrm{C}\left(\mathrm{g} \mathrm{kg}^{-1}\right)$ & 7.1 & Chromic acid oxidation & Walkley and Black (1934) \\
\hline 5. & Cation exchange capacity (meq $100 \mathrm{~g}^{-1}$ ) & 17.6 & Sodium acetate & Jackson (1973) \\
\hline 6. & Mineralizable $\mathrm{N}\left(\mathrm{mg} \mathrm{kg}^{-1}\right)$ & 84.4 & Alkaline permanganate & Subbiah and Asija (1956) \\
\hline 7. & Acetate-extractable $\mathrm{K}\left(\mathrm{mg} \mathrm{kg}^{-1}\right)$ & 82.1 & $1 \mathrm{~N} \mathrm{CH}_{3} \mathrm{COONH}_{4}, \mathrm{pH} 7.0$ & Jackson (1973) \\
\hline 8. & Olsen $\mathrm{P}\left(\mathrm{mg} \mathrm{kg}^{-1}\right)$ & 12.0 & $0.5 \mathrm{M} \mathrm{NaHCO}_{3}, \mathrm{pH} 8.5$ & Olsen et al., (1954) \\
\hline 9. & Inorganic $\mathrm{P}\left(\mathrm{mg} \mathrm{kg}^{-1}\right)$ & 66.9 & Non-ignition & Walker and Adams (1958) \\
\hline 10. & Organic $\mathrm{P}\left(\mathrm{mg} \mathrm{kg}^{-1}\right)$ & 135.6 & Ignition & Walker and Adams (1958) \\
\hline 11. & Total P $\left(\mathrm{mg} \mathrm{kg}^{-1}\right)$ & 206.1 & $\mathrm{Na}_{2} \mathrm{CO}_{3}$-fusion & Jackson (1973) \\
\hline 12. & $\begin{array}{l}\text { Dehydrogenase activity } \\
\left(\mu \mathrm{g} \text { TPF g soil }{ }^{-1} 24 \mathrm{~h}^{-1}\right)\end{array}$ & 215.1 & Colorimetric & Tabatabai (1982) \\
\hline 13. & $\begin{array}{l}\text { Fungal population, CFU } \\
{\text { (propagules } \text { g soil }^{-1} \text { ) }}\end{array}$ & $29.5 \times 10^{3}$ & Serial dilution & Subba Rao (1986) \\
\hline
\end{tabular}
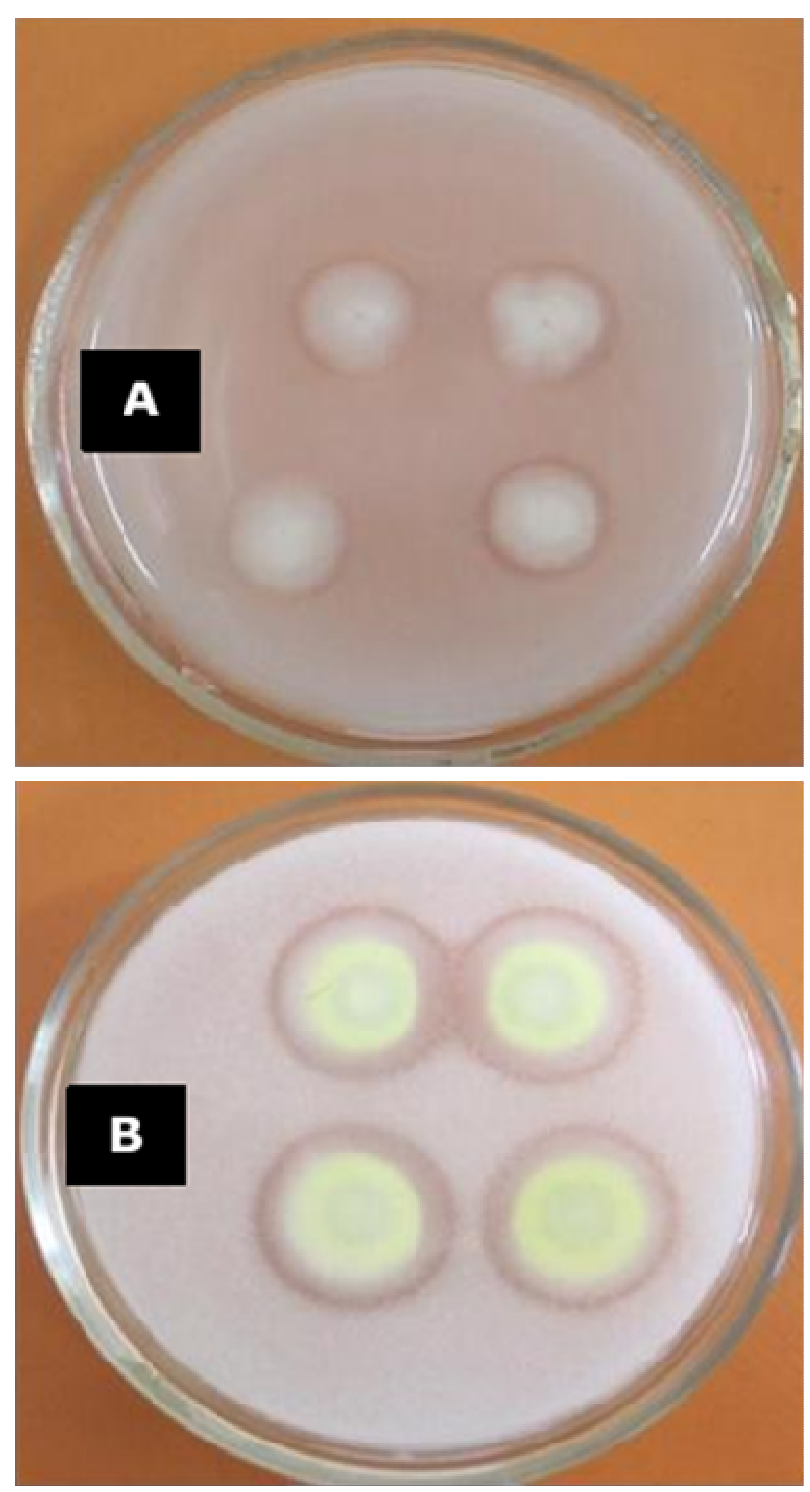

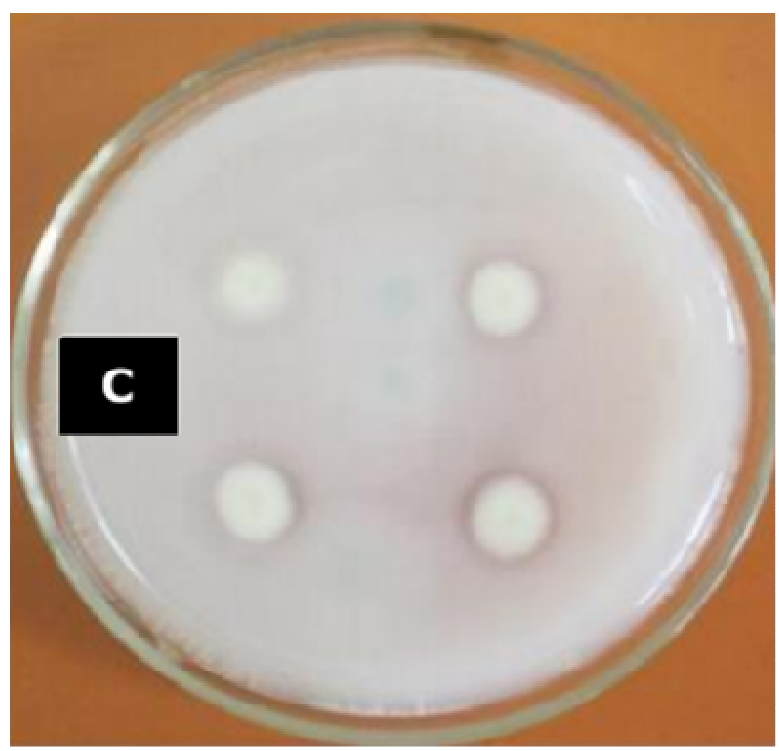

Fig. 1. Phosphate solubilization efficiency of Penicillium strains. (A) P. bilaii strain PB-201; (B) P. bilaii strain PB208 and $(C)$ combination of both strains.

Table 2. Comparative phosphate solubilization efficiency of soil isolates and $P$. bilaii strains.

\begin{tabular}{lc}
\hline Code & Comparative solubilization efficiency* \\
\hline $\mathrm{Pb}_{1}$ & +++++ \\
$\mathrm{Pb}_{2}$ & ++++++ \\
$\mathrm{Pb}_{1}+\mathrm{Pb}_{2}$ & ++++ \\
$\mathrm{F}_{1} \mathrm{~W}_{1}$ & ++ \\
$\mathrm{F}_{2} \mathrm{~W}_{3}$ & +++ \\
$\mathrm{F}_{3} \mathrm{~B}_{1}$ & + \\
\hline
\end{tabular}

*Average of 3 and 7 days of incubation, $\mathrm{Pb}_{1}$ : P. bilaii strain PB-201, $\mathrm{Pb}_{2}$ : P. bilaii strain PB-208 
of wheat by 21.7 and 26.3 per cent, respectively, over $50 \% \mathrm{P}$ alone $\left(\mathrm{T}_{5}\right)$. However, the influence of $\mathrm{T}_{6}$ and $\mathrm{T}_{8}$ on grain and straw yield was at par compared to $\mathrm{T}_{5}$. The treatments $\mathrm{T}_{10}, \mathrm{~T}_{11}$ and $\mathrm{T}_{12}$ increased the grain yield by $9.0,16.3$ and 6.0 per cent, respectively, over $100 \% \mathrm{P}\left(\mathrm{T}_{9}\right)$ alone. However, the effect of all the treatments, except $\mathrm{T}_{11}$, was also at par.

Table 3 reveals that phosphorus content in grain and straw and its uptake significantly increased in soil treated with either phosphate compound and inoculated with PB strains, corresponding to the controls. The table also indicates that the individual PB strain resulted in higher increase in $\mathrm{P}$ content and uptake over their conjoint use with or, without $\mathrm{P}$ fertilization. The inoculation of $\mathrm{Pb}_{2}$ with $50 \% \mathrm{P}\left(\mathrm{T}_{7}\right)$ resulted in highest increase in $\mathrm{P}$ content in grain and straw and its uptake. The increase was by 38.0 and 38.1 per cent for $\mathrm{P}$ content in grain and straw, respectively and 53.4 per cent for $\mathrm{P}$ uptake, over $\mathrm{T}_{9}$.

Forms of P: The levels of inorganic $\left(\mathrm{P}_{\mathrm{i}}\right)$, organic $\left(\mathrm{P}_{\mathrm{o}}\right)$ and total $\mathrm{P}\left(\mathrm{P}_{\mathrm{t}}\right)$ were increased with increasing level of $\mathrm{P}$ fertilization, either inoculated with individual $P$. bilaii strains, or in combination (Table 4). They were also statistically significant compared to their respective control. However, a non-significant decline was observed in Olsen-P when $\mathrm{P}$ fertilization increased from $50 \%$ to $100 \%$ inoculated with individual strains or, conjoint use (Table 4). It is clearly seen from the table that Olsen-P ranged from 11.7 to $15.4 \mathrm{mg} \mathrm{kg}^{-1}$ soil and $T_{7}$ resulted in maximum level amongst the treatments. $\mathrm{P}_{\mathrm{i}}, \mathrm{P}_{\mathrm{o}}$ and $\mathrm{P}_{\mathrm{t}}$ ranged from 63.74 to 81.60, 131.62 to 165.75 and 195.40 to $247.40 \mathrm{mg} \mathrm{kg}^{-1}$ soil, respectively. The share of organic $\mathrm{P}$ to total $\mathrm{P}$ on an average ranged from 16 to 46 per cent among different treatments.

Soil properties: Data pertaining to various soil properties are presented in Table 5. Two strains of $P$. bilaii with different levels of $\mathrm{P}$ showed significant differences in $\mathrm{pH}$ and organic $\mathrm{C}$ over respective controls. An overall decrease was observed in soil $\mathrm{pH}$ in all of the treatments corresponding to the controls. However, an opposite phenomena was recorded in organic $\mathrm{C}$. The treatments failed to influence mineralizable-N and acetate-extractable $\mathrm{K}$ in soil however, a non-significant decline in their levels was observed compared to the controls. Table 5 reveals a significant increase in fungal population (CFU) and DHA activity in soil after harvest. The fungal population and DHA activity of the experiment varied between $67.35 \times 10^{3}$ to $156.25 \times 10^{3}$ CFU and 829.9 to $1385.3 \mathrm{mg} \mathrm{TPF} \mathrm{g}^{-1} 24 \mathrm{~h}^{-1}$, respectively.

\section{DISCUSSION}

In the present study, two strains of $P$. bilaii were tested for their efficiency to solubilize tri-calcium phosphate compared to native fungal isolates present in soil. Higher phosphate solubilization efficiency of the procured $P$. bilaii strains over the soil fungal isolates indicates that whatever phosphate solubilization and, its subsequent availability to wheat occurred was mainly contributed by $P$. bilaii strains. Penicillium strains have been studied for their phosphate solubilizing activity and used as biofertilizers (Whitelaw, 2000). As phosphorus is known to initiate cell division and enlargement processes, the increase in growth parameters among different treatments over their respective controls could probably be due to increased mobilization of phosphorus made soluble by P-solubilizing fungi from soil reserves (Reyes et al., 2002). Improvement in crop growth with inoculation with Psolubilizing microorganisms is reported by many authors (Wakelin et al., 2007; Singh and Reddy, 2011; Patil et al., 2012). Seshadri et al. (2000) reported that the native soil $\mathrm{P}$ is utilized for growth and development of the organism when applied to soil environment. In this experiment, $\mathrm{P}$ was applied in readily soluble form, which perhaps fulfilled the demand for $\mathrm{P}$ by the $P$. bilaii strains. This was probably the reason that the growth parameters were much higher in the treatments with $\mathrm{P}$ fertilization as compared to without $\mathrm{P}$ fertilization, inoculated with $P$. bilaii strains. It may also be because that application of $\mathrm{P}$ fertilizer facilitated proper and timely availability of phosphorus to the crop, resulting in an increase in plant growth. This also indicates that $\mathrm{P}$-solubilizing microorganisms when applied without $\mathrm{P}$ fertilization are not much effective in improving plant growth. Similar kind of observation in maize is also reported by Patil et al. (2012). In addition to solubilization of insoluble phosphates, the Psolubilizing microorganisms are also known to produce phytoharmones, growth promoting substances, vitamins, amino acids and other substances responsible for enhanced plant growth (Singh and Reddy, 2011; Patil et al. 2012). Improvement in wheat growth parameters, as a result of inoculation with $P$. bilaii strains, could also be supported by this. Ramezanpour et al. (2010) reported that inoculation of phosphorus solubilizing bacterial strain of Pseudomonas significantly increased spike length, number of panicle, number of spikelet per panicle and weight of 1000 grains in rice. A similar kind of observation with $P$. bilaii strains is also recorded in this experiment. Improvement in growth parameters perhaps also lead to an increase in yield attributes. This could again be ascribed to adequate $\mathrm{P}$ supply to wheat by the $P$. bilaii strains through phosphate solubilization. Increase in yield attributes also reflected in the yield of wheat.

The highest amount of yield components under the treatment $\mathrm{T}_{7}$ could be explained on the basis that values of the highest available $\mathrm{P}$ was recorded in the same treatment. Under field condition, crop yield depends on the availability of P. A similar kind of result in soil inoculated with $P$. pinophilum in wheat and faba bean is also reported by Wahid and Mehana (2000). They concluded that soil inoculation with $P$. pinophilum resulted in an increase in available $\mathrm{P}$, which in turn gave the highest yield in both crops. It was astonishing 
Table 3. Effect of inoculation of two P. bilaii strains with different levels of phosphorus application on yield, content and uptake of $\mathrm{P}$ in wheat.

\begin{tabular}{|c|c|c|c|c|c|}
\hline \multirow[t]{2}{*}{ Treatments } & \multicolumn{2}{|c|}{ Yield $\left(q\right.$ ha $\left.^{-1}\right)$} & \multicolumn{2}{|c|}{$P$ content $(\%)$} & \multirow[t]{2}{*}{ P uptake $\left(\mathrm{kg} \mathrm{ha}^{-1}\right)$} \\
\hline & Grain & Straw & Grain & Straw & \\
\hline T1: Uninoculated + $0 \% \mathrm{P}$ & 50.6 & 31.0 & 0.22 & 0.16 & 11.8 \\
\hline $\mathrm{T} 2: \mathrm{Pb}_{1}+0 \% \mathrm{P}$ & 53.4 & 35.0 & 0.28 & 0.18 & 16.1 \\
\hline $\mathrm{T} 3: \mathrm{Pb}_{2}+0 \% \mathrm{P}$ & 55.7 & 36.6 & 0.32 & 0.19 & 18.7 \\
\hline $\mathrm{T} 4: \mathrm{Pb}_{1}+\mathrm{Pb}_{2}+0 \% \mathrm{P}$ & 57.8 & 34.5 & 0.27 & 0.17 & 15.1 \\
\hline S.E $E_{m} \pm$ & 2.3 & 1.6 & 0.01 & 0.01 & 1.07 \\
\hline $\operatorname{LSD}(p \leq 0.05)$ & 7.6 & 4.8 & 0.04 & 0.02 & 3.07 \\
\hline T5: Uninoculated $+50 \% \mathrm{P}$ & 54.8 & 33.8 & 0.26 & 0.19 & 15.2 \\
\hline $\mathrm{T} 6: \mathrm{Pb}_{1}+50 \% \mathrm{P}$ & 61.4 & 38.3 & 0.33 & 0.24 & 21.7 \\
\hline $\mathrm{T} 7: \mathrm{Pb}_{2}+50 \% \mathrm{P}$ & 66.8 & 42.7 & 0.40 & 0.29 & 26.5 \\
\hline $\mathrm{T} 8: \mathrm{Pb}_{1}+\mathrm{Pb}_{2}+50 \% \mathrm{P}$ & 60.5 & 34.7 & 0.32 & 0.23 & 19.4 \\
\hline S.E $E_{m} \cdot \pm$ & 2.8 & 2.0 & 0.01 & 0.01 & 1.05 \\
\hline $\operatorname{LSD}(p \leq 0.05)$ & 7.2 & 5.2 & 0.05 & 0.02 & 3.00 \\
\hline T9: Uninoculated $+100 \% \mathrm{P}$ & 56.3 & 34.6 & 0.29 & 0.21 & 17.3 \\
\hline $\mathrm{T} 10: \mathrm{Pb}_{1}+100 \% \mathrm{P}$ & 56.4 & 36.0 & 0.30 & 0.22 & 18.7 \\
\hline $\mathrm{T} 11: \mathrm{Pb}_{2}+100 \% \mathrm{P}$ & 65.4 & 38.6 & 0.36 & 0.23 & 25.2 \\
\hline $\mathrm{T} 12: \mathrm{Pb}_{1}+\mathrm{Pb}_{2}+100 \% \mathrm{P}$ & 59.2 & 35.2 & 0.29 & 0.21 & 17.3 \\
\hline S.E $\mathrm{E}_{\mathrm{m}} . \pm$ & 2.5 & 1.8 & 0.01 & 0.01 & 1.09 \\
\hline $\operatorname{LSD}(p \leq 0.05)$ & 7.2 & 5.0 & 0.04 & 0.02 & 3.02 \\
\hline
\end{tabular}

$\mathrm{Pb}_{1}$ : P. bilaii strain PB-201, $\mathrm{Pb}_{2}$ : P. bilaii strain PB-208, 100\% P: $65 \mathrm{~kg} \mathrm{P}_{2} \mathrm{O}_{5} \mathrm{ha}^{-1}$

Table 4. Effect of inoculation of two $P$. bilaii strains with different levels of phosphorus application on different forms of $\mathrm{P}$ in soil after harvest.

\begin{tabular}{|c|c|c|c|c|}
\hline Treatments & $\begin{array}{c}\text { Olsen P } \\
\left(\mathrm{mg} \mathrm{kg}^{-1}\right)\end{array}$ & $\begin{array}{c}\text { Inorganic P } \\
\left(\mathrm{mg} \mathrm{kg}^{-1}\right)\end{array}$ & $\begin{array}{l}\text { Organic P } \\
\left(\mathrm{mg} \mathrm{kg}^{-1}\right)\end{array}$ & $\begin{array}{c}\text { Total P } \\
\left(\mathrm{mg} \mathrm{kg}^{-1}\right)\end{array}$ \\
\hline T1: Uninoculated $+0 \% \mathrm{P}$ & 11.7 & 63.7 & 131.6 & 195.4 \\
\hline $\mathrm{T} 2: \mathrm{Pb}_{1}+0 \% \mathrm{P}$ & 13.0 & 70.5 & 142.9 & 213.5 \\
\hline $\mathrm{T} 3: \mathrm{Pb}_{2}+0 \% \mathrm{P}$ & 13.5 & 69.9 & 139.7 & 209.7 \\
\hline $\mathrm{T} 4: \mathrm{Pb}_{1}+\mathrm{Pb}_{2}+0 \% \mathrm{P}$ & 13.0 & 71.1 & 145.3 & 216.4 \\
\hline S.E. $E_{m} \cdot \pm$ & 0.55 & 3.00 & 6.84 & 8.71 \\
\hline $\operatorname{LSD}(p \leq 0.05)$ & 1.60 & 8.65 & 10.5 & 17.5 \\
\hline T5: Uninoculated $+50 \% \mathrm{P}$ & 12.3 & 66.3 & 150.3 & 216.7 \\
\hline T6: $\mathrm{Pb}_{1}+50 \% \mathrm{P}$ & 13.7 & 73.9 & 151.2 & 225.3 \\
\hline $\mathrm{T} 7: \mathrm{Pb}_{2}+50 \% \mathrm{P}$ & 15.4 & 71.9 & 145.0 & 217.1 \\
\hline $\mathrm{T} 8: \mathrm{Pb}_{1}+\mathrm{Pb}_{2}+50 \% \mathrm{P}$ & 13.6 & 76.2 & 151.1 & 227.5 \\
\hline S.E. $E_{m} \cdot \pm$ & 0.51 & 3.00 & 6.00 & 8.00 \\
\hline $\operatorname{LSD}(p \leq 0.05)$ & 1.60 & 8.10 & 4.62 & 8.90 \\
\hline T9: Uninoculated $+100 \% \mathrm{P}$ & 12.6 & 69.4 & 166.2 & 235.6 \\
\hline T10: $\mathrm{Pb}_{1}+100 \% \mathrm{P}$ & 13.5 & 80.7 & 164.2 & 245.0 \\
\hline $\mathrm{T} 11: \mathrm{Pb}_{2}+100 \% \mathrm{P}$ & 13.9 & 78.7 & 162.7 & 241.5 \\
\hline $\mathrm{T} 12: \mathrm{Pb}_{1}+\mathrm{Pb}_{2}+100 \% \mathrm{P}$ & 13.4 & 81.6 & 165.7 & 247.4 \\
\hline S.E. $E_{m} \cdot \pm$ & 0.50 & 3.00 & 3.85 & 9.00 \\
\hline $\operatorname{LSD}(p \leq 0.05)$ & 1.50 & 8.53 & 5.00 & 9.88 \\
\hline
\end{tabular}

$\mathrm{Pb}_{1}$ : P. bilaii strain PB-201, $\mathrm{Pb}_{2}$ : P. bilaii strain PB-208, 100\% P: $65 \mathrm{~kg} \mathrm{P}_{2} \mathrm{O}_{5} \mathrm{ha}^{-1}$

to observe that the yield components were not increased further when $\mathrm{P}$ fertilization increased from 50 to $100 \%$, inoculated with Penicillium strains. Therefore, it can be concluded that the initial soil $\mathrm{P}$ was already present in adequate quantity. It means that the adequate amount of $\mathrm{P}$ in the soil provided with enough resources for P-solubilizing microorganisms to provide high levels of available $\mathrm{P}$, while application of high level of $\mathrm{P}$ fertilizer led to an antagonistic interaction with the fungal strains. Thus, it can be concluded that the high rate of $\mathrm{P}$ fertilizer application $\left(65 \mathrm{~kg} \mathrm{P}_{2} \mathrm{O}_{5} \mathrm{ha}^{-1}\right)$ might lead to an antagonistic interaction with $P$. bilaii, especially in soil high in available P. Mehrvarz et al.
(2008) obtained the maximum dry matter yield of 17.2 $\mathrm{t} \mathrm{ha}^{-1}$ with sole application of $60 \mathrm{~kg} \mathrm{ha}^{-1} \mathrm{P}$ fertilizer which was not significantly different from using Pseudomonas petida combined with $60 \mathrm{~kg} \mathrm{ha}^{-1} \mathrm{P}$ fertilizer in barley. Thus, our observation confirms the finding of Mehrvarz et al. (2008). A non-significant decline in yield components with conjoint use of Penicillium strains over their individual use with 50 and $100 \% \mathrm{P}$ indicates that, an antagonistic interaction between the $P$. bilaii strains also existed in this experiment. This antagonistic interaction was also evident in $\mathrm{P}$ content and its uptake by wheat. Patil et al. (2012) also recorded the maximum plant height, cob length and 1000 
Table 5. Effect of inoculation of two P. bilaii strains with different levels of phosphorus application on various soil properties after harvest.

\begin{tabular}{|c|c|c|c|c|c|c|}
\hline Treatments & pH & $\begin{array}{l}\text { Org. C } \\
\left(\mathrm{g} \mathrm{kg}^{-1}\right)\end{array}$ & $\begin{array}{l}\text { Min-N } \\
\left(\mathrm{mg} \mathrm{kg}^{-1}\right)\end{array}$ & $\begin{array}{c}\mathrm{Ac}-\mathrm{K} \\
\left(\mathrm{mg} \mathrm{kg}^{-1}\right)\end{array}$ & $\begin{array}{c}\text { DHA } \\
\left(\mu \mathrm{g} \mathrm{TPF} \mathrm{g} \mathrm{\text {soil } ^ { - 1 }} 24 \mathbf{h}^{-1}\right)\end{array}$ & $\begin{array}{l}\text { Fungal popula- } \\
\text { tion }, \mathrm{CFU} \\
(\text { propagules g } \\
\left.\text { soil }^{-1}, \times 10^{3}\right)\end{array}$ \\
\hline T1: Uninoculated $+0 \% \mathrm{P}$ & 7.41 & 5.4 & 83.7 & 79.8 & 829.9 & 71.3 \\
\hline $\mathrm{T} 2: \mathrm{Pb}_{1}+0 \% \mathrm{P}$ & 7.36 & 5.8 & 83.5 & 79.6 & 954.6 & 79.1 \\
\hline $\mathrm{T} 3: \mathrm{Pb}_{2}+0 \% \mathrm{P}$ & 7.39 & 5.9 & 79.8 & 78.9 & 1205.8 & 108.3 \\
\hline $\mathrm{T} 4: \mathrm{Pb}_{1}+\mathrm{Pb}_{2}+0 \% \mathrm{P}$ & 7.36 & 5.4 & 82.5 & 79.3 & 1310.3 & 121.7 \\
\hline S.E $E_{m} \cdot \pm$ & 0.06 & 0.3 & 2.1 & 2.8 & 79.1 & 4.3 \\
\hline $\operatorname{LSD}(p \leq 0.05)$ & 0.19 & 0.9 & $\mathrm{~ns}$ & $\mathrm{~ns}$ & 227.7 & 12.6 \\
\hline T5: Uninoculated $+50 \% \mathrm{P}$ & 7.32 & 6.1 & 83.8 & 80.6 & 971.6 & 92.0 \\
\hline T6: $\mathrm{Pb}_{1}+50 \% \mathrm{P}$ & 7.28 & 6.3 & 80.3 & 78.3 & 1098.6 & 99.1 \\
\hline $\mathrm{T} 7: \mathrm{Pb}_{2}+50 \% \mathrm{P}$ & 7.21 & 6.7 & 75.2 & 78.8 & 1504.5 & 156.2 \\
\hline $\mathrm{T} 8: \mathrm{Pb}_{1}+\mathrm{Pb}_{2}+50 \% \mathrm{P}$ & 7.31 & 6.3 & 76.7 & 80.3 & 1385.3 & 139.1 \\
\hline S.E $E_{m} . \pm$ & 0.05 & 0.3 & 3.1 & 2.8 & 87.6 & 4.3 \\
\hline $\operatorname{LSD}(p \leq 0.05)$ & 0.19 & 0.9 & ns & ns & 227.7 & 12.6 \\
\hline T9: Uninoculated $+100 \% \mathrm{P}$ & 7.49 & 6.2 & 81.2 & 79.4 & 865.3 & 76.7 \\
\hline T10: $\mathrm{Pb}_{1}+100 \% \mathrm{P}$ & 7.28 & 6.5 & 78.4 & 78.2 & 970.6 & 86.3 \\
\hline $\mathrm{T} 11: \mathrm{Pb}_{2}+100 \% \mathrm{P}$ & 7.34 & 6.6 & 76.9 & 77.2 & 1340.9 & 132.4 \\
\hline $\mathrm{T} 12: \mathrm{Pb}_{1}+\mathrm{Pb}_{2}+100 \% \mathrm{P}$ & 7.41 & 6.4 & 79.7 & 78.6 & 1333.5 & 131.6 \\
\hline S.E $E_{m} \cdot \pm$ & 0.06 & 0.2 & 2.5 & 2.8 & 84.3 & 4.3 \\
\hline $\operatorname{LSD}(p \leq 0.05)$ & 0.19 & 0.9 & ns & ns & 227.7 & 12.6 \\
\hline
\end{tabular}

Org. C: Organic C; Min-N: Mineralizable N; Ac-K: Acetate-extractable K; DHA: Dehydrogenase activity; ns- Non-significant; $\mathrm{Pb}_{1}$ : P. bilaii strain PB-201; $\mathrm{Pb}_{2}$ : P. bilaii strain PB-208; $100 \%$ P: $65 \mathrm{~kg} \mathrm{P}_{2} \mathrm{O}_{5}$ ha $^{-1}$
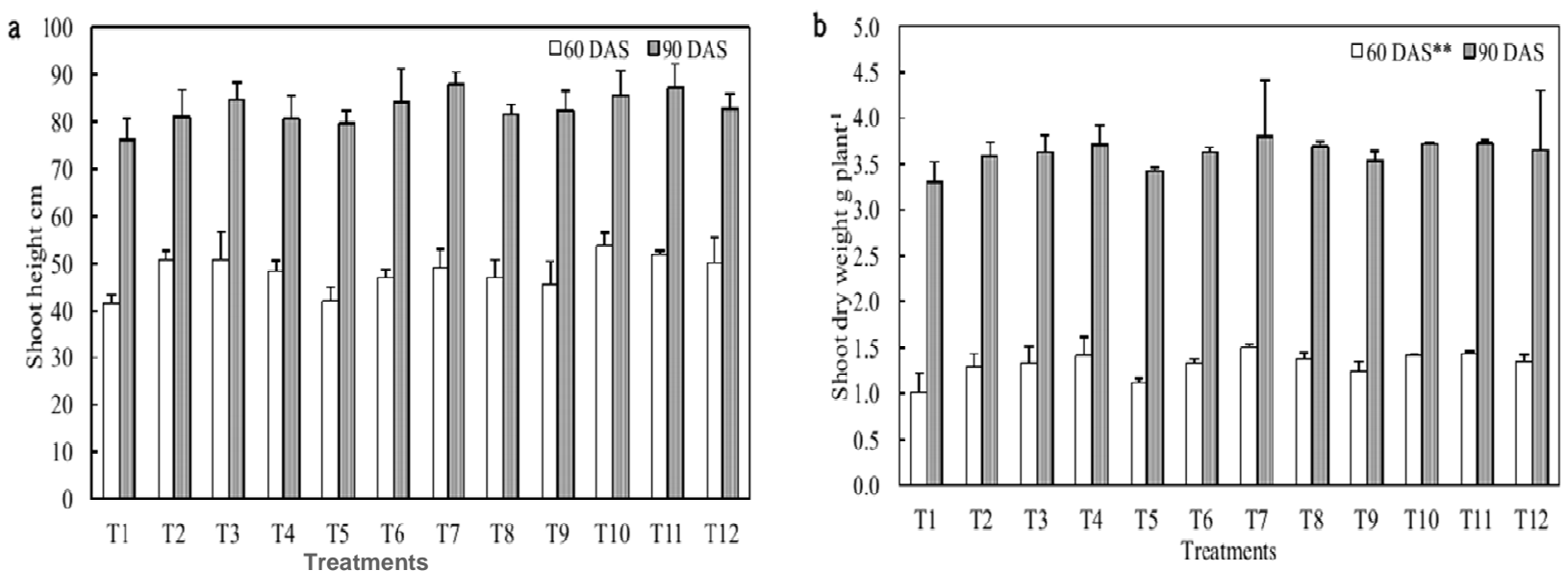

Fig. 2. Effect of inoculation of two P. bilaii strains with different levels of phosphorus application on (a) shoot height and (b) shoot dry weight of wheat at 60 and 90 DAS. Bars indicate standard error $(n=4)$. **Significant at $p \leq 0.05$.

grain weight in maize in the treatment that received $P$. bilaji (Jump start 2) $+75 \mathrm{~kg} \mathrm{P}_{2} \mathrm{O}_{5} \mathrm{ha}^{-1}$, which were at par with the treatments $P$. bilaji (Jump start 1$)+P$. bilaji (Jump start 2) $+75 \mathrm{~kg} \mathrm{P}_{2} \mathrm{O}_{5} \mathrm{ha}^{-1}$ and $P$. bilaji (Jump start 1) $+P$. bilaji (Jump start 2) $+38 \mathrm{~kg} \mathrm{P}_{2} \mathrm{O}_{5}$ $\mathrm{ha}^{-1}$. Therefore, our findings could be supported the observations made by Patil et al. (2012). Dual inoculation has often been shown to have no effect, or even a negative effect on plant growth and yield (Owen et al., 2014). For instance, positive growth responses have been reversed by dual inoculation, even though colonization rates of the multiinoculants remained the same (Dodd and RuizLozano, 2012). The particular mechanism mediating the antagonism could not be identified from this single study and requires further investigation to confirm such observation. Gulden and Vessey (2000) observed that $P$. bilaii inoculation increased root hair production in pea and, they concluded that $P$. bilaii has the potential to greatly influence the nutrient absorptive capacity of roots. This increase in nutrient absorptive capacity could result in an increase in $\mathrm{P}$ uptake in crops. Highest increase in shoot $\mathrm{P}$ uptake also occurred in treatment that had the highest level of Olsen-P. This suggests that uptake of $\mathrm{P}$ by wheat was not necessarily associated with $\mathrm{P}$ solubilization by the fungus. Increased capacity of roots to absorb $\mathrm{P}$ could have also accounted for improved $\mathrm{P}$ uptake.

The major portion of the $\mathrm{P}$ that is applied to soil rapidly becomes converted into inorganic and organic fractions which are poorly available to plants for uptake (Brady and Weil, 2008). Filamentous fungi, 

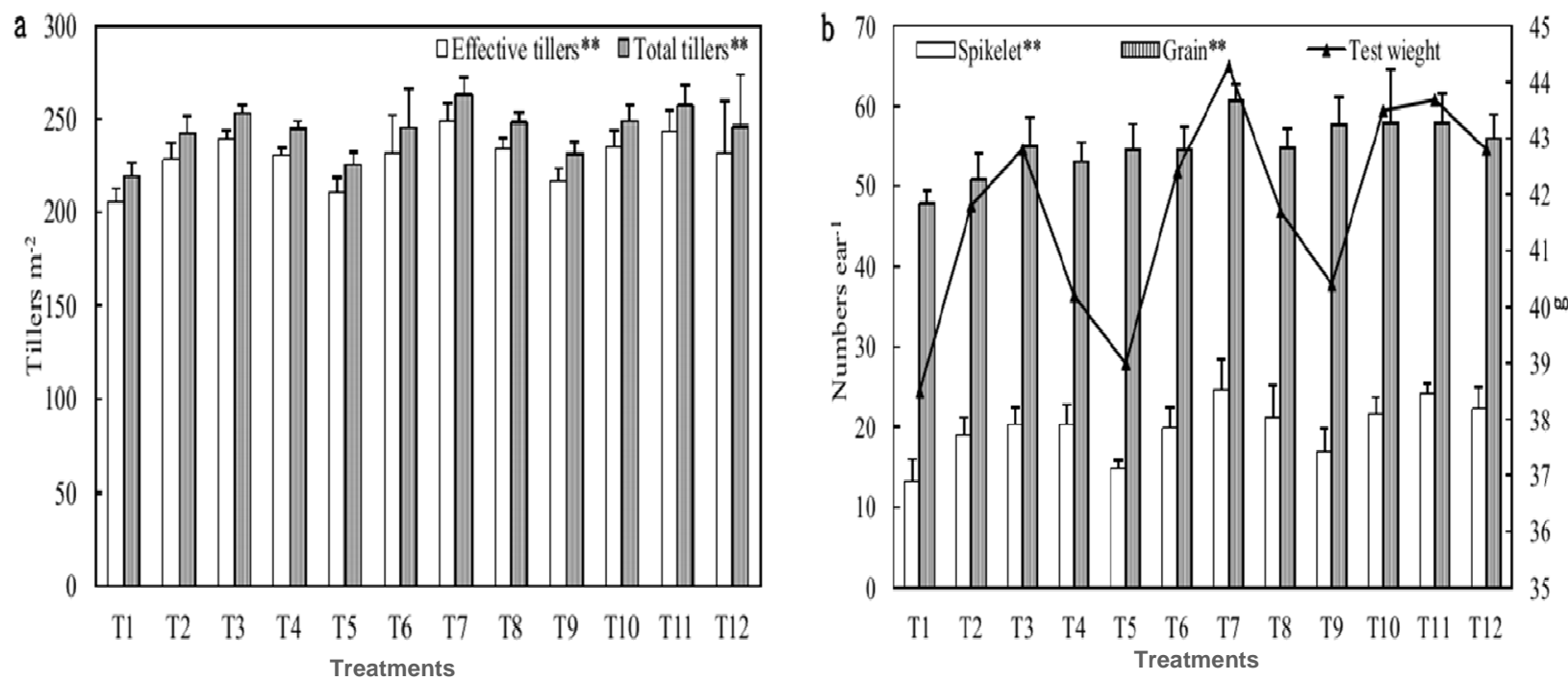

Fig. 3. Effect of inoculation of two P. bilaii strains with different levels of phosphorus application on (a) effective and total tillers and (b) yield attributing characters of wheat at harvest. Bars indicate standard error $(n=4)$. **Significant at $p \leq 0.05$.

mainly Aspergillus and Penicillium are widely used to solubilize insoluble phosphates (Reyes et al., 2006). This ability is generally associated to the release of organic acids, such as citric acid, oxalic acid, malic acid and gluconic acid with ion chelation solubilize inorganic P sources (Reyes et al., 2006; Gadagi et al., 2007). Addition of $P$ through readily soluble form as well as solubilization of inorganic P-fraction by the $P$. bilaii strains was mainly responsible for increased level of Olsen-P in soil after wheat harvest. Moreover, in absence of $\mathrm{P}$ fertilization, the $P$. bilaii strains were also able to solubilize insoluble phosphates that led to an increase in Olsen-P over the control. However, determination of the type of organic acids released and their quantification would reveal much more information regarding the difference between the two strains in solubilizing inorganic P. The decrease in Olsen-P level with concomitant increase in $\mathrm{P}$ fertilization has resulted in an increase in inorganic and organic $\mathrm{P}$ level in soil. This suggests that with the increase in $\mathrm{P}$ fertilization rate, $\mathrm{P}$ became converted into inorganic and organic $\mathrm{P}$ in soil. This is obvious but however, it seems that inoculation of $P$. bilaii strains did not have any influence in increasing Olsen-P level with the increasing rate of $\mathrm{P}$ fertilization. This result perhaps indicates that $P$. bilaii strains are not much effective in increasing available $P$ in soil when combined with high rate of $\mathrm{P}$ fertilization.

Many microorganisms can mobilize $\mathrm{P}$ from inorganic compounds simply by lowering $\mathrm{pH}$ occurring as a result of general metabolic activity (Zaidi and Khan, 2007). The lowering of soil $\mathrm{pH}$ in this experiment suggests the release of organic acids by the fungal strains. The synthesis and discharge of organic acid by the fungal strains could acidify their surrounding environment that ultimately lead to the release of $\mathrm{P}$ ions from the insoluble $\mathrm{P}$ mineral by $\mathrm{H}^{+}$substitution. Nonethe- less, a dramatic shift in $\mathrm{pH}$ would be required to increase its solubility, and, therefore mechanisms such as secretion of strongly chelating organic acids (or the conjugate anions) must be expressed to affect $\mathrm{P}$ solubilization (Wakelin et al., 2004). P fertilization along with $\mathrm{P}$ solubilizing microorganism has led better crop growth, which in turn released good amount of root exudates and assimilable organic $\mathrm{C}$ to the soil. This was probably the reason that organic carbon content was greater in inoculated treatments as compared to un -inoculated ones. This result is in agreement with the findings of Singh and Reddy (2011) who observed an increase in soil organic carbon when inoculated with $P$. oxalicum over control. Improved crop growth due to increased availability of $\mathrm{P}$ by $P$. bilaii strains has definitely increased the demand for other nutrients by wheat crop. Therefore, levels of mineralizable-N and acetate-extractable $\mathrm{K}$ were declined in inoculated treatments over the controls. The bulk increase in fungal population and dehydrogenase activity was probably due to good growth of the treated fungus and other fungal genera in soil and, thereby enhancing their activity in soil. Plant's active root system releases about $17 \%$ of photosynthate captured in the form of organic compounds into the rhizosphere, most of which is available to the soil microorganisms for their growth and optimum activity (Nguyen, 2003). Dehydrogenase activity in soil depends on the content of soluble organic carbon and, the increased organic $\mathrm{C}$ in soil could enhance the soil enzyme activities (Debnath et al., 2015). Release of root exudates and assimilable organic $\mathrm{C}$ to the soil by wheat perhaps maintained a favorable condition for microbial growth and activity which, in turn could have also resulted in an increase in fungal population and dehydrogenase activity in inoculated treatments. 


\section{Conclusion}

From these results it was found that the influence of the two $P$. bilaii strains was not similar in terms of measured parameters in this experiment. Even, their conjoint use did not have the most effective influence over their individual use with or, without $\mathrm{P}$ fertilization. One of the major reasons for such difference is attributed to the nature and amount of organic acids released by them. Another reason is extended to the genotype and physiological state of the inoculated strains. The size and composition of the populations sustained by the rhizosphere is determined by several environmental factors like $\mathrm{pH}$, mineral nutrients, water content, crop species and the presence of other microbial species. Therefore, selection of specific strain for a particular crop is of paramount importance and can support the shift towards sustainable production system. The phosphatic fertilizer in current use scenario requires a greater input that cannot be afforded by the small to marginal farmers of the developing nations like India. With the results of this experiment, it is possible to reduce the recommended dose of $\mathrm{P}$ fertilizer added by $50 \%$ without reducing yield, if wheat is inoculated with $\mathrm{P}$-solubilizing fungi such as P. bilaii.

\section{REFERENCES}

Brady, N.C. and Weil, R.R. (2008). The Nature and Properties of Soils. Prentice Hall, New Delhi.

Cunningham, J.E. and Kuiack, C. (1992). Production of citric and oxalic acids and solubilization of calcium phosphate by Penicillium bilaji. Appl. Environ. Microbiol. 58: 1451-1458.

Debnath, S., Patra, A.K., Ahmed, N., Kumar, S. and Dwivedi, B.S. (2015). Assessment of microbial biomass and enzyme activities in soil under temperate fruit crops in north western himalayan region. J. Soil Sci. Plant Nutri.http://dx.doi.org/10.4067/S071895162015005000059 .

Dodd, I.C. and Ruiz-Lozano, J.M. (2012). Microbial enhancement of crop resource use efficiency. Curr. Opinion Biotech. 23: 236-242.

Gadagi, R.S., Shin, W.S. and Sa, T.M. (2007). Malic acid mediated aluminum phosphate solubilization by Penicillium oxalicum CBPS-3F-Tsa isolated from Korean paddy rhizosphere soil. Dev. Plant Soil Sci. 102: 285290.

Gomez, K.A. and Gomez, A.A. (1984). Statistical Procedure for Agricultural Research. John Wiley and Sons, New York.

Gulden, R.H. and Vessey, J.K. (2000). Penicillium bilaii inoculation increases root-hair production in field pea. Can. J. Plant Sci. 80: 801-804.

Havlin, J.L., Beaton, J.D., Tisdale, S.L. and Nelson, W.L. (2009). Soil Fertility and Fertilizers- An Introduction to Nutrient Management. PHI Learning Pvt. Ltd, New Delhi.

Jackson, M.L. (1973). Soil Chemical Analysis. Prentice Hall, New Delhi.

Khan, M.S., Zaidi, A. and Wani, P.A. (2007). Role of phosphate-solubilizing microorganisms in sustainable agri- culture - a review. Agron. Sustain. Dev. 27: 29-43.

Khan, K.S. and Joergensen, R.G. (2009). Changes in microbial biomass and $\mathrm{P}$ fractions in biogenic household waste compost amended with inorganic $\mathrm{P}$ fertilizers. Biores. Tech. 100: 303-309.

Kucey, R.M.N. (1988). Effect of Penicillium bilaji on the solubility and uptake of $\mathrm{P}$ and micronutrients from soil by wheat. Can. J. Soil Sci. 68: 261-270.

Kucey, R.M.N., Janzen, H.H. and Legget, M.E. (1989). Microbial mediated increase in plant available phosphorus. Adv. Agron. 42: 199-228.

Mehrvarz, S., Chaichi, M.R. and Alikhani, H.A. (2008). Effects of phosphate solubilizing microorganisms and phosphorus chemical fertilizer on yield and yield components of barely (Hordeum vulgare L.). Am-Euras. J. Agric. Environ. Sci. 3: 822-828.

Nguyen, C. (2003). Rhizodeposition of organic C by plants: mechanism and controls. Agron. 23: 375-396.

Olsen, S.R., Cole, C., Watanbe, F.S. and Dean, L.A. (1954). Estimation of available phosphorus in soils by extraction with sodium bicarbonate. Circular 939, U.S. Dept. Agric., Washington (DC), pp 939.

Owen, D., Williams, A.P., Griffith, G.W. and Withers, P.J.A. (2014). Use of commercial bio-inoculants to increase agricultural production through improved phosphorus acquisition. Appl. Soil Ecol. 86: 41-54.

Patil, P.M., Kuligod, V.B., Hebsur, N.S., Patil, C.R. and Kulkarni, G.N. (2012). Effect of phosphate solubilizing fungi and phosphorus levels on growth, yield and nutrient content in maize (Zea mays). Karnataka J. Agric. Sci. 25: 58-62.

Piper, C.S. (1967). Soil and Plant Analysis. Asia Publishing House, Bombay.

Ramezanpour, M.R., Popov, Y., Khavazi, K. and Rahmani, H.A. (2010). Genetic diversity and efficiency of indole acetic acid production by the isolates of fluorescent Pseudomonas from rhizosphere of rice (Oryza sativa L.). Am-Euras. J. Agric. Environ. Sci. 7: 103-109.

Relwani, L., Krishna, P. and Reddy, M.S. (2008). Effect of carbon and nitrogen sources on phosphate solubilization by a wild-type strain and UV-induced mutants of Aspergillus tubingensis. Curr. Microbiol. 57: 401-406.

Reyes, I., Bernier, L. and Antoun, H. (2002). Rock phosphate solubilization and colonization of maize rhizosphere by wild and genetically modified strains of Penicillium rugulosum. Microb. Ecol. 44: 39-48.

Reyes, I., Valery, A. and Valduz, Z. (2006). Phosphatesolubilizing microorganisms isolated from rhizospheric and bulk soils of colonizer plants at an abandoned rock phosphate mine. Plant Soil. 287: 69-75.

Rodriguez, H., Gonzalez, T., Goire, I. and Bashan, Y. (2004). Gluconic acid production and phosphate solubilization by the plant growth-promoting bacterium Azospirillum spp. Naturewissenschaften. 91: 552-555.

Saber, W.I.A., Ghanem, K.M. and El-Hersh, M.S. (2009). Rock phosphate solubilization by two isolates of Aspergillius niger and Penicillium sp. and their promotion to mung bean plants. Res. J. Microbiol. 4: 235-250.

Seshadri, S., Muthukumarasamy, R. and Lakshminarasimhan, C. (2000). Solubilization of inorganic phosphates by Azospirillium halopraeferans. Curr. Sci. 79: 565567.

Singh, H. and Reddy, M.S. (2011). Effect of inoculation with phosphate solubilizing fungus on growth and nutrient uptake of wheat and maize plants fertilized with rock 
phosphate in alkaline soils. Europ. J. Soil Biol. 47: 30-34.

Subba Rao, N.S. (1986). Advances in Agricultural Microbiology. Oxford and IBH Publications Company, India.

Subbiah, B.V. and Asija, G.L. (1956). A rapid procedure for the determination of available nitrogen in soils. Curr. Sci. 25: 259-260.

Sundara Rao, W.V.B. and Sinha, M.K. (1963). Phosphate dissolving microorganisms in the soil and rhizosphere. Indian J. Agric. Sci. 33: 272-278.

Tabatabai, M.A. (1982). Soil enzymes. Methods of Soil analysis. Part 2. Chemical and Biochemical properties. Agronomy Monograph No. 9. ASA and SSSA. Madison, Wisconsin, pp 903-947.

Tarafdar, J.C. and Rao, A.V. (1996). Contribution of Aspergillus strains to acquisition of phosphorus by wheat (Triticum aestivum L.) and chick pea (Cicer arietinum L.) grown in a loamy sand soil. Appl. Soil Ecol. 3: 109114.

Wahid, O.A. and Mehana, T.A. (2000). Impact of phosphate solubilizing fungi on the yield and phosphorus uptake by wheat and faba bean plants. Microbiol. Res. 155: 221 $-227$.

Wakelin, S.A., Warren, R.A., Harvey, P.R. and Ryder, M.H. (2004). Phosphate solubilization by Penicillium spp. closely associated with wheat roots. Biol. Fert. Soil. 40:
$36-43$.

Wakelin, S.A., Gupta, V.V.S.R., Harvey, P.R. and Ryder, M.H. (2007). The effect of Penicillium fungi on plant growth and phosphorus mobilization in neutral to alkaline soils from southern Australia. Can. J. Microbiol. 53: $106-115$

Walker, T.W. and Adams, A.F.R. (1958). Studies on soil organic matter: I. Influence of phosphorus content of parent materials on accumulation of carbon, nitrogen, sulfur and organic phosphorus in grassland soils. Soil Sci. 85: 307-318.

Walkley, A.H. and Black, I.A. (1934). Estimation of soil organic carbon by the chromic acid titration methods. Soil Sci. 37: 29-38.

Whitelaw, M.A. (2000). Growth promotion of plants inoculated with phosphate-solubilizing fungi. Adv. Agron. 69: 99-151.

Xiao, C.Q., Chi, R.A., Huang, X.H., Zhang, W.X. et al. (2008). Optimization for RP solubilization by phosphate -solubilizing fungi isolated from phosphate mines. Ecol. Eng. 33: 187-193.

Zaidi, A. and Khan, M.S. (2007). Stimulatory effects of dual inoculation with phosphate solubilizing microorganisms and arbuscular mycorrhizal fungus on chickpea. Aus. $J$. Experim. Agric. 47: 1016-1022. 